\title{
PERAN IBU ASUH DALAM MENGIMPLEMENTASIKAN BUDAYA BERBAHASA INGGRIS DI LEMBAGA PENGEMBANGAN BAHASA ASING NURUL JADID
}

\author{
Imania* \& Moh. Rifa'i** \\ Universitas Nurul Jadid \\ *imai00905@gmail.com \\ **mohrifai83@gmail.com
}

\begin{abstract}
The purpose of this paper is to find out how the Foster Mother owns the role to assist and become a leader to cultivate English in the Foreign Language Development Institution, so that the English-language culture of students can take part in this era by preaching religious knowledge in English. With its role, Foster Mother as a determinant of success of institutional students run with management functions which include: Planning, organizing, movement, control and evaluation. As well as foster mothers also play with their role, such as using a democratic style, providing motivation and giving awards to students so that students can carry out an English-language culture within the Foreign Language Development Institution. And in the English-speaking environment Nurul Jadid Islamic Boarding School has the characteristic which always be use English for about 24 hours in a day, conducting intensive studies, and speaking English with Islamic values. This research use desciptive qualitative approach. Data collection conducted by researchers is interview techniques. The object of research is the English-language culture which in this case is the leadership role of the Guardian Asuh.
\end{abstract}

Keywords: Leadership, English Culture and Santri

\begin{abstract}
Abstrak : Tujuan penulisan ini ialah untuk mengetahui bagaimana cara Ibu Asuh berperan untuk mendampingi sekaligus menjadi pemimpin untuk menbudidayakan bahasa inggris di lingkungan Lembaga Pengembangan Bahasa Asing, sehingga dengan budaya berbahasa inggris santri dapat berkiprah di zaman ini dengan mendakwahkan ilmu agamanya dengan berbahsa inggris. Dengan perannya, Ibu Asuh sebagai penentu keberhasilah peserta didik lembaga menjalankan dengan fungsifungsi manajemen yang meliputi : Perencanaan, pengorganisasian, pergerakan, pengontrolan dan evaluasi. Serta Ibu asuh juga bemain dengan perannya yaitu seperti halnya menggunakan gaya demokratis, memberikan motivasi dan memberikan penghargaan terhadap peserta didik agar peserta didik dapat melakukan budaya berbahasa inggris di lingkungan Lembaga Pengembangan Bahasa Asing. Dan dalam lingkungan berbahasa Inggris Pondok Pesantren Nurul Jadid memiliki ciri khas ialah dengan selalu menggunakan bahasa inggris 24 jam, melakukan kajian intensif, serta berbahasa Inggris dengan nilai-nilai ke Islaman. Penelitian ini menggunakan
\end{abstract}


pendekatan deskriptif-kualitatif. Pengumpulan data yang dilakukan peneliti ialah teknik wawancara. Objek penelitian adalah budaya berbahasa Inggris yang dalam hal ini dengan peran kepemimpinan Wali Asuh.

Kata Kunci : Kepemimpinan, Budaya Bahasa Inggris dan Santri

\section{PENDAHULUAN}

Islamic boarding school atau bisa disebut dengan pesantren merupakan tempat menetap para santri dan kiai, yang berfungsi sebagai tempat mengaji ilmu agama. ${ }^{1}$ Dan dapat juga ditarik benang merah sebagai istilah pesantren merupakan sebuah lembaga yang menampung para santriwan dan santriwati untuk mempelajari ilmu agama dibawah tangung jawab Kiai. ${ }^{2}$ Di pondok pesantren, santri mempelajari ilmu agama dengan kitab kuning yang disebut dengan arab gundul. Maka dari itulah pesantren juga disebut pendidikan khas yang dimiliki oleh Negara Indonesia. Selain itu, dilihat dari sejarahnya pesantren juga termasuk tempat tonggak perjuangan kemerdekaan Republik Indonesia. ${ }^{3}$

Beruntunglah bagi para generasi yang masih tetap andil belajar di sebuah pondok pesantren, karena sebagai seorang santri pastilah mempelajari dan bahkan terbekali dengan ilmu agama. Dengan itu, pesantren dapat mencetak para santri dalam lingkup ilmu pengetahuan tentang agama sekaligus akhlaknya. Oleh sebab itu, memang tidak salah jika beberapa pendapat memapaparkan bahwa santri bisa belajar dengan kitab dan bahasa arab dengan wujud pencitraan santri berkeagamaan dipondok pesantren. Namun hal ini akan bernilai positif dan mendapat nilai plus artinya nilai tambah, jika dari kalangan santri dapat terbekali dengan bahasa asing yakni bahasa inggris. Hingga peran santri sangatlah berpotensi pada zamannya, kehidupan santri yang kian termasuk era refolusi industri 4.0. Dengan membekali pribadi santri dengan ilmu agama dan bahasa inggris, maka kemampuan santri mendapat kombinasi ilmu yakni ilmu agama dan ilmu bahasa inggris. Sebagaimana disampaikan Saidna Zulfiqar and Bin Tahir dalam penelitiannya yakni, This educational institution's learning system is

${ }^{1}$ Saiful Mujab, 'Memahami Tradisi Spiritual Pesantren (Sebuah Analisis Sosio-Historis Terhadap Spiritualitas Pesantren Di Indonesia)', Jurnal Asketik, 1.2 (2016), 83.

${ }^{2}$ Herman, 'Sejarah Pesantren Di Indonesia', Jurnal AL-Ta'dib, 6.2 (2013), 148.

3 Abdul Kodir Al-Baekani, Mansyur Srisudarso, and Muhamad Reza Pahlevi, 'Pandangan Para Ustad Dan Santri-Santri Terhadap Pelajaran Bahasa Inggris Di Pondok Pesantren Salafiyah Darul Ulum Karawang', Jurnal Pendidikan Unsika, 5.2 (2017), 117. 
developed and modernized by applying the combination of religious and general subjects. Especially, Arabic and English in teaching and learning process which use in daily communication inside of pesantren. The obligation to use foreign languages was intended to improve the students' knowledge in Islamic study and science through their languages skill. ${ }^{4}$

Salah satu syarat utama dalam merespon tantangan zaman globalisasi ini ialah santri diharapkan mampu berbahasa inggris dan dapat mempraktekkannya sejak usia dini. ${ }^{5}$ Oleh karenanya, penerapan dalam berbahasa asing sangatlah dibutuhkan dalam pentas dakwah terhadap para Muslimin Wal Muslimat. Hal ini sebagaimana di contohkan oleh tokoh William Henry Quilliam penduduk asli Inggris yang memeluk agama Islam pada tahun 1887 berusia 31 tahun, dan menggantikan namanya menjadi sebutan Abdullah. Quilliam menjadi pemimpin muslim inggris yang mengeluarkan banyak fatwa, hingga menumbuhkan Islam yang luar biasa di Inggris dan menerbitkan buku yang berjudul "Faith of Islam". Pada suatu ketika, ia hijrah meninggalkan inggris atas dasar penganiayaan dan permusuhan hingga mengalami "Islamophobia" di negara Inggris. ${ }^{6}$ Artinya Quillim menjalankan dakwahnya di Negara Inggris.

Maka dari itulah dengan tuntutan zaman ini, santri diharapkan tidak hanya dapat memahami teknologi dengan baik namun dituntut pula untuk berterampil dalam berbahasa inggris, seperti halnya bahasa inggris menjadi bahasa Internasional yang digunakan sebagai alat komunikasi antar Negara. ${ }^{7}$ Untuk mengembangkan bahasa inggris terhadap para generasi, Kehadiran Lembaga Pengembangan Bahasa Asing (LPBA) yang berada dibawah naungan Pondok Pesantren sangatlah diharapkan guna mengembangkan nilai-nilai kepesantrenan dengan berbahasa inggris. Sebagaimana harapan Kyai pertama untuk mencetak santri yang mampu bersaing dikencah percaturan dunia Internasional yang handal dan berkualitas tinggi di bidang bahasa Inggris dengan tetap memperkuat pemahaman agama, hal ini sebagi ciri khas santri Pondok Pesantren Nurul Jadid.

\footnotetext{
4 Saidna Zulfiqar and Bin Tahir, 'The Attitude of Santri and Ustadz Toward Multilingual Education at Pesantren', International Jurnal of Language Linguistics, 3.4 (2015), 210 <https://doi.org/10.11648/j.ijll.20150304.13>.

5 Al-Baekani, Srisudarso, and Pahlevi.

${ }^{6}$ Chaerul Mundir, 'Islam Di Inggris', Jurnal Riblah, II.1 (2015), 108.

7 Dina Novita Wijayanti, 'Pembelajaran Efektif Bahasa Inggris Melalui Lagu Anak-Anak Untuk Siswa Madrasah Ibtidaiyah (MI)’, Elementary, 4.1 (2016), 124-25.
} 
Maka dari itulah sebagai pemimpin lembaga yang berada dibawah naungan pondok pesantren, yang lumrah dipanggil dengan sebutan "Ibu Asuh", memainkan perannya sebagai penanggung jawab atas terwujudnya program-program lembaga hingga tercipta lingkungan berbahasa inggris di lingkungan Lembaga Pengembangan Bahasa Anggris yang berada dibawah naungan pondok pesantren. Peran Ibu asuh ialah mampu mengerakkan bawahannya kearah tujuan lembaga. ${ }^{8}$ Karena tanpa kepemimpinan yang baik maka akan sulit utuk mencapai tujuan sebuah lembaga. Ketika suatu lembaga didampingi oleh kepemimpinan yang demikian akan mendapatkan manfaat besar terhadap lembaga sendiri. Dengan tatanan manajemen yang baik Ibu Asuh juga mendorong dan membangun prinsip-prinsip manajemen seperti halnya perencanaan, pengorganisasian, melaksanakan kegiatan atau program, melakukan pengawasan, sehingga dapat dipastikan manajemen yang berada di lembaga tersebut akan terkelolah dengan baik dikarenakan pemimpin yang mampu menghendel lembaganya. ${ }^{10} \mathrm{Hal}$ inilah yang menjadikan daya tarik peneliti untuk terus meneliti lebih dalam tetang peran Ibu Asuh untuk dapat melahirkan budaya berbahasa inggris di Lembaga Pengembangan Bahasa Asing.

\section{METODE PENELITIAN}

Tujuan Penelitian ini adalan untuk mengetahui bagaimana cara Ibu Asuh yang berperan untuk mengimplematasikan budaya berbahasa asing dengan programprogram yang ada di Lembaga Pengembangan Bahasa Asing yang beradah di bawah naungan Pondok Pesantren Nurul Jadid dan mengetahui budaya yang berada di lingkungan Lembaga Pengembangan Bahasa Asing yang beradah di bawah naungan Pondok Pesantren Nurul Jadid. Subjek penelitian di Lembaga Pengembangan Bahasa Asing Pondok Pesantren Nurul Jadid karanganyar Paiton Probolinggo. Penelitian ini menggunakan pendekatan deskriptif-kualitatif. Pengumpulan data yang dilakukan peneliti ialah teknik wawancara guna mendapatkan informasi secara langsung dan

\footnotetext{
8 Agus Yudi Harsono, Supratomo, and Muhammad Faid, 'Analisis Gaya Kepemimpinan Dan Komunikasi Organisasi Antara Atasan-Bawahan Dalam Membangun Budaya Organisasi Di Lingkungan Seretariat DPRD Kota Bengkulu', Jurnal Komunikasi KAREBA, 4.3 (2015), 329.

9 Endah Susetyo Indriyati, 'Pengaruh Gaya Kepemimpinan, Motivasi Dan Disiplin Kerja Terhadap Kinerja Karyawan Dengan Pemahaman Etika Kerja Islami', Upajiwa Dewantara, 1.2 (2017), 135.

10 Ahmad Janan Asifudin, 'Manajemen Pendidikan Untuk Pondok Pesantren', Jurnal Manajemen Pendidikan Islam, 1.2 (2016), 363.
} 
mendapat gambaran peran Ibu Asuh dengan kepemimpinannya serta dengan fungsifungsi manajemen yang di terapkan yang sesuai dengan visi dan misi Lembaga Pengembangan Bahasa Asing Nurul Jadid Paiton Probolinggo. Ibu Asuh juga memaikan perannya dengan gaya yang dimilikinya yakni dengan gaya demokrasi, memberikan motivasi dan memberikan penghargaan terhadap peserta didik. Objek penelitian adalah budaya berbahasa Inggris yang dalam hal ini dengan peran kepemimpinan Wali Asuh.

\section{KAJIAN KONSEPTUAL}

\section{Kepemimpinan Ibu Asuh}

Pada dasarnya semua orang bisa menjadi pemimpin termasuk pula wanita. Posisi perempuan dapat diibaratkan sebuah pondasi yang kokoh dalam suatu bangunan. Oleh karenanya, peran perempuan tidak cukup hanya sebagai objek pembangun namun juga sebagai subjek pembangunan. ${ }^{11}$ Sebagai seorang pemimpin perempuan atau disebut Ibu Asuh yang dijadikan pusat penanggung jawab atas kepemimpinannya. Dengan demikian, tugas utama menjadi pemimpin adalah pertanggung jawaban terhadap sang Khalik. ${ }^{12}$ Hal ini sepertihalnya disampaikan oleh Rasulullah Saw. dalam hadisnya, yakni :

"Sesungguhnya setiap diri kalian ialah seorang pemimpin dan yang akan dimintai pertanggu jawabannya. Seperti halnya dalam penguasaan ialah pemimpin, seorang suami ialah pemimpin bagi keluarganya, seorang istri ialah pemimpin dirumah suaminya, pelayan ialah pemimpin dalam mengelolah harta yang dimiliki oleh tuannya dan yang akan dimintai pertanggung jawabannya atas kepemimpinannya." H.R. Ibn Umar r.a.

Di dalam lembaga pendidikan "pimpinan" ibarat motor penggerak serta penentu arah jalannya organisasi. ${ }^{13}$ Sehingga untuk mencapai sasaran yang sangat

${ }^{11}$ St Zakiah, 'Kepemimpinan Perempuan Pada Madrasah Aliyah Di Kabupaten Bone', Jurnal AlMaiyyah, 11.1 (2018), 60.

12 Hasan Zaini, 'Manajemen Pendidikan Dalam Perspektif Al-Qur'an', Jurnal Al-Fikrah, 1.1 (2013), 8.

${ }^{13}$ Herawati Syamsul, 'Penerapan Kepemimpinan Kepala Sekolah Dalam Meningkatkan Kinerja Guru Pada Jenjang Sekolah Menengah Pertama (SMP)', Jurnal Idarah, I.2 (2017), 275. 
maksimal pemimpin perlu memberi pengarahan mengetahui ${ }^{14}$ dan memberikan wawasan $^{15}$ agar mencapai tujuan yang ditetapkan. ${ }^{16}$ Dalam menjalankan roda organisasi pemimpin dituntut memiliki intelegensia yang tinggi dengan tujuan agar mencapai tujuan lembaga yang efektif dan efisien, seperti halnya ; menciptakan, merencanakan, mengorganisasikan, memberi motivasi, berkomunikasi dan mengevaluasi. ${ }^{17}$

Tugas seorang pemimpin pada dasarnya sangat luas dan komleks. Sedangkan menurut kebijakan pendidikan Nasional yang telah ditetapkan terhadap seorang pemimpin ialah terdapat tujuh peran utama yaitu sebagai : educator, manager, supervisor, leader, wirausaha, administator dan penciptaan iklim kerja. ${ }^{18}$

a. Pendidik (Educator)

Peran pemimpin sebagai pendidik ialah, pemimpin dapat melaksanakan kegiatan perencanaan yang dapat menyusun perangkat pembelajaran, kegiatan pengelolaan yang dapat menerapkan pembelajaran yang efektif dan efisien, dan kegiatan evaluasi pembelajaran yang memilih metode yang tepat dan dapat memberikan tindak lanjut yang diperlukan sehingga dapat dilakukannya perbaikan dilain waktu. Peran inilah yang merupakan penciptaan guru yang professional yang bisa membimbing siswa dan para guru.

b. Pengelolah (Manager)

Peran pemimpin ialah dapat melaksanakan pengelolahan kurikulum, ketenaga kerjaan, peserta didik, hubugan sekolah dan masyarakat, ketata usahaan lembaga, sara dan prasarana. Sehingga sebagai pemimpin lembaga dapat melakukan pendekatan baru dalam rangka meningkatkan kapasitas

${ }^{14}$ Agus Jamaludin, 'Pengaruh Gaya Kepemimpinan Terhadap Kinerja Karyawan Pada PT Kaho Indah Citra Garment Jakarta', Jounal of Applied Business and Economics, 3.3 (2017), 163.

${ }^{15}$ Hedra Hadiwijaya, 'Pengaruh Gaya Kepemimpinan Dan Motivasi Terhadap Kinerja Karyawan Pada Unit Usaha Pengembangan Dan Lingkungan PT Perkembangan Mitra Organ Batu Raja', Jurnal Ekonomi Dan Bisnis (JENIUS), 5.1 (2017), 37.

${ }^{16}$ Michael Sugianto, 'Evaluasi Gaya Kepemimpinan CEO Dalam Mencapai Kesuksesan Start-Up Business Maha Siswa Di Universitas Ciputra', Jurnal Manajemen Dan Start-Up Bisnis : PERFORMA, 1.6 (2017), 720.

17 Muhammad Fadli, 'Manajemen Peningkatan Mutu Pendidikan', TADRIB: Jurnal Studi Manajemen Pendidikan, 1.2 (2017), 223.

18 Hasan Baharun, 'Peningkatan Kompetensi Guru Melalui Sistem Kepemimpinan Kepala Madrasah', Jurnal Ilmu Tarbiyah At-Tajdid, 6.1 (2017), 6-8. 
sekolah. Kegiatan operasional dapat dilakukan prosedur kerja seperti; perencanaan, pengorganisasian, pergerakan dan pengawasan.

c. Supervisor

Fungsi pemimpin ialah membina keprofessionalan terhadap guru dan tenaga kependidikan. Karena itulah, sebagai pemimpin perlu melakukan observasi kelas dan melakukan pertemuan agar bisa memberikan pengarahan dan solusi terhadap prolematika yang dialami oleh bawahannya.

d. Pemimpin (Leader)

Dengan perannya sebagai pemimpin berfungsi menggerakkan bawahannya agar mencapai tujuan lembaga. Sehingga pemimpin dituntut menerapkan prinsip dan metode kepemimpinan yang mengedepankan keteladanan, pemberdayaan staf dan pemotivasian.

e. Wirausahaan (Wirausaha)

Pemimpin berfungsi sebagai inspirator dengan munculnya ide kreatif dan inovatif dalam mengelolah lembaga.

f. Administator

Arti dari pemimpin sebagai administator ialah pemimpin yang bertanggung jawab atas kegiatan administrasi ketatausahaan lembaga dengan tujuan mendukung kegiatan pembelajaran.

\section{g. Penciptaan Iklim Kerja}

Sebagai seorang pemimpin sebagai klim kerja ialah berfungsi meningkatkan semangat kerja para pendidik, sehingga terdorong untuk bekerja yang sehat hingga mencapai tujuan lembaga.

\section{Budaya Berbahasa Inggris}

Budaya menurut Teasur Bahasa (TB) berati adat istiadat, kebiasaan dan akal budi. ${ }^{19}$ Sedangkan definisi budaya ialah sesuatu yang dapat mempengaruhi tingkat pengetahuan dan sebuah gagasan yang ada dalam pikiran manusia sehingga kebudayaan bersifat abstrak dalam hidup kesehariannya. ${ }^{20}$

Bahasa asing sepertihalnya bahasa inggris telah dikenal oleh pendidikan di Indonesia dan menjadi bahasa kebutuhan warga dunia. Dengan mempelajari

19 Tim Redaksi, 'Tesaurus Bahasa Indonesia Pusat Bahasa', 2008, p. 80.

${ }^{20}$ Rina Devianty, 'Bahasa Sebagai Cermin Kebudayaan', Jurnal Tarbiyah, 24.2 (2017), 231. 
bahasa asing tidaklah cukup hanya mempelajari bahasanya tanpa mempelajari budayanya. Sehingga pelajar harus mengetahui kapan bahasa itu bisa digunakan. ${ }^{21}$ Sehingga dalam mempelajari bahasa inggris diharapkan memiliki kemampuan, yaitu ; pengembangan potensi berkomunikasi, mempunyai kesadaran atas pentingnya bahasa inggris guna meningkatkan daya saing bangsa dalam masyarakat global dan mengembangkan pemahaman peserta didik kaitannya antara budaya dengan bahasa. ${ }^{22}$ Hal ini sebagaimana sebuah Hadits yang berbunyi :

"Barang siapa yang mempelajari bahasa suatu kaum, maka dia akan selamat dari tipu daya kaum tersebut".

Dalam membudidayakan bahasa inggris dapat dilakukan dengan keterampilan berbicara atau "Speaking", karena speaking in english sangatlah ditekankan dalam penguasaan berbahasa Inggris. ${ }^{23}$

\section{PERAN IBU ASUH DI LINGKUNGAN LEMBAGA PENGEMBANGAN BAHASA ASING}

Kebijakan, keputusan dan kepemimpinan tertinggi yang ada di kawasan pondok pesantren tentunya dihendel oleh pengasuh atau disebut dengan Kiai yang menjadi pusat kepemimpinan pesantren. Untuk membagi tugasnya maka peran Ibu Asuh menjadi penanggung jawab kedua yang diberikan kepercayaan langsung oleh sang Kiai. Sehingga Ibu Asuh memainkan perannya sebagai pendidik sekaligus pemimpin bagi peserta didik lembaga dalam membudidayakan bahasa inggris, yakni dengan cara:

Pertama ialah dengan berkepemimpinan demokratis. Ciri khas yang ada dalam diri kepemimpinan Ibu Asuh melalui gaya kepemimpinan demokratis. Gaya kepemimpinan demokratis yang dilakukan Ibu Asuh ialah terjun langsung terhadap peserta didik yang dilakukan berulang-ulang dan memberikan kasih sayang terhadap peserta didik. Sehingga peran ibu asuh dapat menjadi ibu sekaligus dewan konsultan terhadap peserta didik. Sepertihalnya menerima curahan hati peserta didik untuk melanjutkan studi dan masalah-masalah yang berkaitan dengan kegiatan kebahasaan

\footnotetext{
${ }^{21}$ Laelah Azizah S Suhaeb, 'Memaknai Budaya Lokal Dan Global Dalam Pengajaran Bahasa Asing', Jurnal Lingua Didaktika, 3.2 (2010), 146.

22 Ade Alfa Pramudia, 'Manajemen Pembelajaran Bahasa Inggris Pada SMAN 3 Batu Sangkar', Jurnal Al-Fikerah, 5.2 (2017), 142.

${ }^{23}$ Sulasih, 'Pembelajaran Bahasa Inggris Melalui Multimedia', Jurnal Informatika, 2.4 (2017), 201.
} 
di lembaga sehingga dengan itu peserta didik merasa terbekali akan masukan melalui berbagi cerita.

Gaya kepemimpinan demokratis tersebut juga berkesinambungan dengan teori yang dipaparkan oleh Mardiana bahwasanya gaya demokratis ialah cara pemimpin terbuka terhadap bawahannya dengan mendiskusikan keberadaannya dalam menjalankan tugas sesuai dengan kesepakatan bersama. ${ }^{24}$ Sehingga pemimpin bertanggung jawab dan memerankan tugasnya untuk mengontrol, mengarahkan dan mengkoordinasi bawahannya. ${ }^{25}$

Kedua ialah memberikan motivasi. Dengan memberikan motivasi terhadap peserta didik maka akan semakin terbekali untuk tetap kuat dalam menjalankan kebahasaan di lembaga. Sepertihalnya Ibu Asuh tetap memberikan pencerahan betapa pentingnya belajar ilmu agama dan berbahasa Inggris, sehingga Ibu Asuh dapat memberikan motivasi melalui cerita-cerita yang membangkitkan semangat mereka untuk tetap siap menghadapi tantangan kehidupan dalam berbahasa Inggris. Dengan mengurangi rasa keterbukaan terhadap para santri Ibu Asuh juga berperan humoris dalam pribadinya sehingga rasa ingin terus memberikan motivasi terasa semakin kuat untuk diberikan.

Pemberian motivasi tersebut juga berkesinambungan dengan teori yang sampaikan oleh Harini Fajar dkk. bahwasanya motivasi merupakan sikap mental manusia yang memberikan dorongan yang ditujuan untuk tujuan tertentu. ${ }^{26}$ Sehingga dengan mendapatkan motivasi seseorang akan terdorong unuk melakukan hal yang baru, sehingga dapat diarahkan kepada tujuan.

Ketiga ialah Penghargaan. Dengan adanya penghargaan terhadap yang paling aktif berbahasa dan bagus dalam bertutur kata dalam berbahasa inggris akan mendapat penghargaan sebagai bentuk menambah semangat dalam membudi dayakan bahasa inggris. Dengan itulah, santri akan semakin aktif dalam berbahasa inggris.

24 Mardiana, 'Pengasuh Gaya Kepemimpinan Demokratis Terhadap Kinerja Pegawai Pada Kantor Sekretariat Daerah Kota Samarinda', eJurnal Ilmu Pemerintahan, 2.1 (2014), 1815.

25 Syafiqul Umam, M. Soe'oed Hakam, and Heru Susilo, 'Pengaruh Gaya Kepemimpinan Demokratik Terhadap Motivasi Kerja Dan Kinerja Karyawan', Jurnal Administrasi Bisnis, 21.1 (2015), 2.

${ }^{26}$ Harini Fajar, Tjutju Yuniarsih, and Eeng Ahman, 'Pengaruh Pemberian Pengharargaan Dan Hukuman Terhadap Motivasi Kerja Serta Implikasinya Pada Kinerja Karyawan PT Difa Kreasi Di Cikarang-Bekasi', Jurnal Ilmu Manajemen Dan Bisnis, 9.1 (2018), 37. 
Dalam bentuk penghargaan merupakan kata kunci agar meningkatkan motivasi peserta didik untuk melakukan sesuatu yang diharapkan, dalam rangka mengurangi rasa lelah dalam melaksana pekerjaan. ${ }^{27}$

\section{INTELEGENSIA IBU ASUH DI LINGKUNGAN LEMBAGA BAHASA ASING}

Kemajuan dan perkembangan lembaga dapat diakibatkan siapa pemimpinnya. Sehingga kualitas dari pemimpin seringkali dianggap sebagai faktor terpenting dalam keberhasilan atau kegagalan organisasi. ${ }^{28}$ Peran Ibu Asuh juga dapat melaksanakan fungsi-fungsi manajemen yang meliputi Planning, Organizing, Actuating, Controling dan Evaluating, yakni sebagai berikut :

\section{Perencanaan (Planning)}

Perancanaan yang dilakukan oleh kepemimpinan Ibu Asuh di Lembaga Pengembangan Bahasa Asing Pondok Pesantren Nurul Jadid dalam menerapkan budaya bahasa inggris ialah diawali dengan pembentukan organisasi NATO (Nahdlatut Tholabah), yakni terdri dari gebernur yang akan mengawasi jalannya kegiatan ekstrakurikuler perdevisi ; defisi keilmuan, kebahasan dan kesenian. Sehingga dengan pembentukan tugas tersebut dapat dilanjut dengan menyusun program kerja (PROKER) yang akan dilaksanakannya kegiatan harian, mingguan dan bulanannya. Dan dalam PROKER tersebut dilakukan dengan bermusyawaroh dengan anggota NATO (Nahdlatut Tholabah), sehingga hasil dari pada musyawaroh dapat dijadikan sebuah acuan ataupun sebagai pedoman dalam menjalankan misi kelembagaan dan melaksanakan kegiatan untuk mencapai visi kelembagaan di Lembaga Pengembangan Bahasa Asing Pondok Pesantren Nurul Jadid.

Dari hasil penelitian di lapangan jika dibandingkan dengan teori yang diambil oleh peneliti tidak jauh berbeda. Bahwasanya dalam organisasi sangat dibutuhkan

${ }^{27}$ Florbela Monica de Araujo, Desak Ketut Sintaasih, and I Gede Riana, 'Peran Motivasi Dalam Memediasi Pengaruh Sistem Reward Terhadap Kinerja Pegawai', E-Jurnal Ekonomi Bisnis Dan Bisnis Universitas Udayana, 1.8 (2019), 44.

28 Susilo Toto Raharjo and Durrotun Nafisah, 'Analisis Pengaruh Gaya Kepemimpinan Terhadap Kepuasan Kerja, Komitmen Organisasi Dan Kinerja Karyawan (Studi Kasus Empiris Pada Departemen Agama Kabupaten Kendal Dan Departemen Agama Kota Semarang)', Jurnal Studi Manajemen Dan Organisasi, 3.2 (2006), 70. 
sebuah perencanaan untuk memikirkan kondisi sekarang dan masa lalu serta memikirkan masa depan serta berusaha mewujudkan terhadap yang dipikirkan. ${ }^{29}$ Brooks juga memaparkan pendapatnya dalam penelitiannya Agustomi bahwasanya perencanaan sangatlah mutlak diperlukan dan bagaimana pelaksanaan dari perencanaan tersebut. ${ }^{30}$

\section{Pelaksanaan Pengorganisasian (Organizing)}

Sebagai seorang pemimpin harus bisa memilih personalian yang pas diserahkan pertanggung jawabannya, agar para penanggung jawab bekerja yang sesuai dengan skill dan kemampuannya. Oleh karena itu, kepemimpinan Ibu Asuh dapat memilih anggota NATO sebagai orang-orang yang bisa mempertanggung jawabkan tugasnya dengan baik yang sesuai dengan skil perdevisi. Hal tersebut akan membantu pemimpin dalam bertugas seperti halnya memilih anggota NATO perdevisi seperti : tugas gubernur yang bisa menghendel seluruh kegiatan ekstrakurikuler lembaga dengan basis bahasa inggris, devisi kependidikan yang bisa mengatur jalannya kegiatan yang bermutu keilmuan, devisi kesenian yang bisa meningkatkan skil seni dengan berbahasa inggris dan devisi kebahasaan yang bisa mengontrol pengucapan dan tata bahasa benar salahnya dalam berbahasa inggris. Sehingga dapat disimpulkan secara esensi peran Ibu Asuh dapat menempatkan para penanggung jawab atas berjalannya kegiatan kelembagaan maksimal dapat dilaksanakan dan memahami topoksi jabatan yang diemban oleh perdevisi.

Dengan hasil penelitian yang telah dilakukan oleh kepemimpinan Ibu Asuh yang membagi tugas dalam berorganisasi (menerapkan job decription) yang dapat dijalankan sesuai dengan tugas dan kewewenangan perdevisi. Pemberian jabatan dapat dilakukan guna mengetahui kewajiban atau tanggung jawab terhadap jabatan perorangan. ${ }^{31}$ Sebagai seorang Ibu Asuh perlu memberikan arahan sehingga

29 Agustomi Masik, 'Hubungan Modal Sosial Dan Perencanaan', Jurnal Perencanaan Wilayah Dan Kota, 16.3 (2005), 3.

${ }^{30}$ Masik.

31 Bayu Satria Yudha, Imam Haryono, and Litasari Widyastuti Suwarsono, 'Perancangan Job Description Berdasarkan Kerangka Business Process Pada CV.Gradient (Job Description Design Based on Businees Process Framework at CV.Gtadient)', E-Proceeding of Engineering, 4.2 (2017), 2531. 
terdapat kominikasi terhadap bawahannya agar bawahan dapat bekerja sesuai dengan rencana yang telah ditatapkan. ${ }^{32}$

\section{Pelaksanaan Pergerakan (Actuating)}

Pengembangan budaya berbahasa inggris tentunya patutlah bersandar dengan perintah yang sesuai dengan peraturan yang ada untuk terlaksananya kegiatan kebahasaan seperti : Pidato, debat, terjeman, bercerita, mengarang, menerjemah, parade puisi, diskusi, listening, drama, audio visual, dan percakapan. Proses pengarahan dapat dilakukan oleh kepemimpinan ibu asuh di Lembaga Pengembangan Bahasa Asing Pondok Pesantren Nurul Jadid yang menimbulkan bawahan atau anggota NATO mengerti dan memahami apa yang menjadi tanggung jawabnya sebagai anggota keorganisasian. Sehingga dengan pengarahan itulah Ibu Asuh dapat membimbing dan mengajarkan terhadap anggota NATO sesuai dengan petunjuk peraturan keorganisasian, baik secara tertulis maupun secara lisan.

Jika dibandingkan dengan teorinya George R. Terry tentang proses pengarahan, bahwasanya proses pengarahan ialah suatu tindakan yang dilakukan semua anggota organisasi dan berusaha mencapai sasaran agar sesuai dengan rencana organisasi. Hal ini sangatlah penting dilakukan oleh seorang pemimpin untuk menggerakkan bawahannya agar bawahannya bekerja sesuai dengan tugasnya dan penuh tanggung jawab. ${ }^{33}$

\section{Pelaksanaan Pengawasan (Controling)}

Peran Ibu Asuh untuk mengawasi jalannya kegiatan yang ada di Lembaga Pengembangan Bahasa Asing Pondok Pesantren Nurul Jadid dengan memonitoring dan mensupervisi jalannya kegiatan ekstrakurikuler yang di jalankan oleh anggota NATO. Sehingga dengan pengawasan Ibu Asuh akan mengetahui kegiatan yang masih belum berjalan dengan baik, yang masih tidak sejalan dengan planning PROKER. Dan Bagi pesrta didik yang melanggar kebahasaan akan dikenakan sangsi sebagaiman peraturan yang berlaku, dan tidak berjalannya

32 I Wayan Lanang Pastika, Gede Santanu, and Kadek Eni Marheni, 'Penerapan Konsep Pengorganisasian Dan Pengarahan Pada PT Bayus Cargo Bandung, Bali', Jurnal Bisnis Dan Kewirausahaan, 12.3 (2016), 200.

33 Rifki Faisal Miftaahul Zanah and Jaka Sulaksana, 'Pengaruh Fungsi Manajemen Terhadap Kepuasan Kerja Karyawan (Suatu Kasus Di Home Industri Asri Rahayu Di Wilayah Majalengka)', Jurnal Ilmu Pertanian Dan Peternakan, 4.2 (2016), 159. 
kebahasaan yang dilakukan oleh anggota NATO akan disangsi dua kali lipat dari pada peserta didik sebagaimana kebijakan Ibu Asuh. Sehingga budaya kebahasaan dan kegiatan dapat terawasi kesehariaannya oleh kepemimpinan Ibu Asuh. Namun, ketika Ibu Asuh mengalami halangan dalam pengawasan maka sudah ada yang menanganinya, yaitu anggota pengurus yang juga mengawasinya. Dalam pengawasan itulah sebagai Ibu Asuh mendapat tambahan informasi atau pengalaman dan mendapat kritikan dari anggota NATO sebagai ajang evaluasi.

Dengan adanya pengawasan sangat penting dilakukan agar kegiatan tidak melenceng dari tujuan. Pengawasan juga tidak hanya berlangsung disaat pelaksanaan saja namun perlu dilakukan pengawasan ketika saat perencanaan program kerja dan pengorganisasian. ${ }^{34}$

\section{Pelaksanaan Evaluasi (Evaluating)}

Dalam melakukan proses evaluasi di lembaga, Ibu Asuh memaparkan aktifitas yang sudah berjalan dengan baik maupun yang tidak. Dan tentunya dalam suatu evaluasi tidakhanya memaparkan kendala saja namun juga memberikan masukan atas perkembangan peserta didik agar tetap membudayakan bahasa asing di Lembaga. Evaluasi tersebut dilakukan dua minggu satu kali sehingga pemantauan berkelanjutan secara terus menerus.

Harapan evaluasi ialah mengetahui penyebab dan mencari upaya untuk mengatasi kekurangan kegiatan yang masih kurang maksimal, sehingga sasaran akhir dapat tercapai. ${ }^{35}$ Sehingga dengan evaluasi dapat melakukan perbaikan dari progrm kerja yang terdahulu.

\section{LINGKUNGAN BUDAYA BAHASA INGGRIS DI LEMBAGA PENGEMBANGAN BAHASA ASING PONDOK PESANTREN NURUL JADID}

\section{Budaya berbahasa Inggris}

a. Dengan kebudayaan berbahasa inggris di Lembaga Pengembangan Bahasa Asing, sebagaiman dilakukan peserta didik lembaga dalam kesehariannya ialah

${ }^{34}$ Zanah and Sulaksana.

35 Enny Mar'atus Sholihah and Setya Haksama, 'Pengaruh Leadership Terhadap Kinerja Rumah Sakit Umum Daerah Dr. Soegiri Lamongan', Jurnal Administrasi Kesehatan Indonesia Volume, 2.4 (2014), 275. 
meggunakan bahasa inggris selama 24 jam, dan tidak diperkenankan berbahasa lain kecuali bahasa inggris di area lembaga, sehingga seloga yang dipaparkan oleh Ibu Asuh ialah "No speaking without english, No reading without english and No singing exept english" sehingga budaya tersebut tetap tertanam mindset yang baik bahwasanya betapa pentingnya berbahasa inggris dalam kehidupan sehari-hari. Sehingga mindset untuk terus belajar bahasa inggris tetap menjadi kebiasaan para santri disetiap harinya.

b. Peserta didik juga di haruskan untuk selalu berkomunikasi aktif dalam berbahasa inggris serta menggunakan bahasa yang "Native Speaker" agar tidak terbiasa dengan bahasa ibu. Sepertihalnya peserta didik menggunakan bahasa "ah, aduh, sih, beh, woy, mah".

c. Dengan kegiatan "Reading day on new paper" yang dilakukan oleh santri lembaga setiap hari guna mendapat informasi lebih dan mendapat tambahan kosa kata. Sehingga santri terbiasa membaca bacaan dalam texs berbahasa inggris.

\section{Melaksanakan Kajian-Kajian Intensif}

Dengan melaksanakan kajian yang intensif, santri yang berada di lembaga pengembangan bahasa asing belajar memfokuskan terhadap bahasa inggris. Sehingga untuk membudidayakan berbahasa inggris di pondok pesantren lebih banyak.

\section{Menerapkan Nilai-Nilai Keislaman}

Sesuai dengan visi kelembagaan untuk belajar bahasa inggris ialah sebagai alat untuk berpertisipasi dimedia dakwah berdasarkan nilai-nilai kepesantrenan. Maka dari itulah penerapan kegiatan extrakurikuler sepertihalnya : pidato, drama, puisi, diskusi, percakapan, terjemah, mengarang dan cerdas-cermat tidak jauh dari tematema yang bersangkut pautan dengan dasar kepesantrenan.

\section{KESIMPULAN}

Peran Ibu Asuh memiliki peluang yang sangat besar untuk menciptakan lingkungan berbahasa inggris di Lingkungan Lembaga Pengembangan Bahasa Asing. Melalui pola kepemimpinan dan intelegensia Ibu Asuh dapat semakin meningkatkan lingkunga yang sangat erat akan bahasanya, sehingga dapat dikatakan budidaya berbahasa asing di lembaga dapat terapresiasi dengan efektif dan efisien. Karena 
dengan kepemimpinan Ibu Asuh yang semakin tersistem dengan baik akan semakin menumbuhkan budaya asing yang baik sehingga para generasi santri semakin terbekali dengan bahasa inggris dan juga agamanya.

\section{DAFTAR PUSTAKA}

Al-Baekani, Abdul Kodir, Mansyur Srisudarso, and Muhamad Reza Pahlevi, 'Pandangan Para Ustad Dan Santri-Santri Terhadap Pelajaran Bahasa Inggris Di Pondok Pesantren Salafiyah Darul Ulum Karawang', Jurnal Pendidikan Unsika, 5 (2017), 117

Araujo, Florbela Monica de, Desak Ketut Sintaasih, and I Gede Riana, 'Peran Motivasi Dalam Memediasi Pengaruh Sistem Reward Terhadap Kinerja Pegawai', E-Jurnal Ekonomi Bisnis Dan Bisnis Universitas Udayana, 1 (2019), 44

Asifudin, Ahmad Janan, 'Manajemen Pendidikan Untuk Pondok Pesantren', Jurnal Manajemen Pendidikan Islam, 1 (2016), 363

Baharun, Hasan, 'Peningkatan Kompetensi Guru Melalui Sistem Kepemimpinan Kepala Madrasah', Jurnal Ilmu Tarbiyah At-Tajdid, 6 (2017), 6-8

Devianty, Rina, 'Bahasa Sebagai Cermin Kebudayaan', Jurnal Tarbiyah, 24 (2017), 231

Fadli, Muhammad, 'Manajemen Peningkatan Mutu Pendidikan', TADRIB : Jurnal Studi Manajemen Pendidikan, 1 (2017), 223

Fajar, Harini, Tjutju Yuniarsih, and Eeng Ahman, 'Pengaruh Pemberian Pengharargaan Dan Hukuman Terhadap Motivasi Kerja Serta Implikasinya Pada Kinerja Karyawan PT Difa Kreasi Di Cikarang-Bekasi', Jurnal Ilmu Manajemen Dan Bisnis, 9 (2018), 37

Hadiwijaya, Hedra, 'Pengaruh Gaya Kepemimpinan Dan Motivasi Terhadap Kinerja Karyawan Pada Unit Usaha Pengembangan Dan Lingkungan PT Perkembangan Mitra Organ Batu Raja', Jurnal Ekonomi Dan Bisnis (JENIUS), 5 (2017), 37

Harsono, Agus Yudi, Supratomo, and Muhammad Faid, 'Analisis Gaya Kepemimpinan Dan Komunikasi Organisasi Antara Atasan-Bawahan Dalam Membangun Budaya Organisasi Di Lingkungan Seretariat DPRD Kota Bengkulu', Jurnal Komunikasi KAREBA, 4 (2015), 329

Herman, 'Sejarah Pesantren Di Indonesia', Jurnal AL-Ta'dib, 6 (2013), 148

Indriyati, Endah Susetyo, 'Pengaruh Gaya Kepemimpinan, Motivasi Dan Disiplin Kerja Terhadap Kinerja Karyawan Dengan Pemahaman Etika Kerja Islami', Upajiwa Dewantara, 1 (2017), 135

Jamaludin, Agus, 'Pengaruh Gaya Kepemimpinan Terhadap Kinerja Karyawan Pada PT Kaho Indah Citra Garment Jakarta', Jounal of Applied Business and Economics, 3 (2017), 163

Mardiana, 'Pengasuh Gaya Kepemimpinan Demokratis Terhadap Kinerja Pegawai Pada Kantor Sekretariat Daerah Kota Samarinda', eJurnal Ilmu Pemerintahan, 2 (2014), 1815

Masik, Agustomi, 'Hubungan Modal Sosial Dan Perencanaan', Jurnal Perencanaan Wilayah Dan Kota, 16 (2005), 3

Mujab, Saiful, 'Memahami Tradisi Spiritual Pesantren (Sebuah Analisis Sosio-Historis Terhadap Spiritualitas Pesantren Di Indonesia)', Jurnal Asketik, 1 (2016), 83

Mundir, Chaerul, 'Islam Di Inggris', Jurnal Riblah, II (2015), 108 
Pastika, I Wayan Lanang, Gede Santanu, and Kadek Eni Marheni, 'Penerapan Konsep Pengorganisasian Dan Pengarahan Pada PT Bayus Cargo Bandung, Bali', Jurnal Bisnis Dan Kewirausahaan, 12 (2016), 200

Pramudia, Ade Alfa, 'Manajemen Pembelajaran Bahasa Inggris Pada SMAN 3 Batu Sangkar', Jurnal Al-Fikrah, 5 (2017), 142

Raharjo, Susilo Toto, and Durrotun Nafisah, 'Analisis Pengaruh Gaya Kepemimpinan Terhadap Kepuasan Kerja, Komitmen Organisasi Dan Kinerja Karyawan (Studi Kasus Empiris Pada Departemen Agama Kabupaten Kendal Dan Departemen Agama Kota Semarang)', Jurnal Studi Manajemen Dan Organisasi, 3 (2006), 70

Redaksi, Tim, 'Tesaurus Bahasa Indonesia Pusat Bahasa', 2008, p. 80

Sholihah, Enny Mar'atus, and Setya Haksama, 'Pengaruh Leadership Terhadap Kinerja Rumah Sakit Umum Daerah Dr. Soegiri Lamongan', Jurnal Administrasi Kesehatan Indonesia Volume, 2 (2014), 275

Sugianto, Michael, 'Evaluasi Gaya Kepemimpinan CEO Dalam Mencapai Kesuksesan Start-Up Business Maha Siswa Di Universitas Ciputra', Jurnal Manajemen Dan Start-Up Bisnis : PERFORMA, 1 (2017), 720

Suhaeb, Laelah Azizah S, 'Memaknai Budaya Lokal Dan Global Dalam Pengajaran Bahasa Asing', Jurnal Lingua Didaktika, 3 (2010), 146

Sulasih, 'Pembelajaran Bahasa Inggris Melalui Multimedia', Jurnal Informatika, 2 (2017), 201

Syamsul, Herawati, 'Penerapan Kepemimpinan Kepala Sekolah Dalam Meningkatkan Kinerja Guru Pada Jenjang Sekolah Menengah Pertama (SMP)', Jurnal Idarah, I (2017), 275

Umam, Syafiqul, M. Soe'oed Hakam, and Heru Susilo, 'Pengaruh Gaya Kepemimpinan Demokratik Terhadap Motivasi Kerja Dan Kinerja Karyawan', Jurnal Administrasi Bisnis, 21 (2015), 2

Wijayanti, Dina Novita, 'Pembelajaran Efektif Bahasa Inggris Melalui Lagu AnakAnak Untuk Siswa Madrasah Ibtidaiyah (MI)', Elementary, 4 (2016), 124-25

Yudha, Bayu Satria, Imam Haryono, and Litasari Widyastuti Suwarsono, 'Perancangan Job Description Berdasarkan Kerangka Business Process Pada CV.Gradient (Job Description Design Based on Businees Process Framework at CV.Gtadient)', E-Proceeding of Engineering, 4 (2017), 2531

Zaini, Hasan, 'Manajemen Pendidikan Dalam Perspektif Al-Qur'an', Jurnal Al-Fikrah, 1 (2013), 8

Zakiah, St, 'Kepemimpinan Perempuan Pada Madrasah Aliyah Di Kabupaten Bone', Jurnal Al-Maiyyah, 11 (2018), 60

Zanah, Rifki Faisal Miftaahul, and Jaka Sulaksana, 'Pengaruh Fungsi Manajemen Terhadap Kepuasan Kerja Karyawan (Suatu Kasus Di Home Industri Asri Rahayu Di Wilayah Majalengka)', Jurnal Ilmu Pertanian Dan Peternakan, 4 (2016), 159

Zulfiqar, Saidna, and Bin Tahir, 'The Attitude of Santri and Ustadz Toward Multilingual Education at Pesantren', International Jurnal of Language Linguistics, 3 (2015), 210 <https://doi.org/10.11648/j.ijll.20150304.13> 